\title{
Proposing a New Phonological Variety of Nigerian English
}

\author{
Acheoah John Emike \\ Department of European Languages, Federal University, Birin-Kebbi \\ actualemike@gmail.com
}

\begin{abstract}
This study proposes a phonological variety of Nigerian English - Career Nigerian English (CNE). It is a variety spoken by those whose career-driven inclinations and latent talents have improved their spoken English in spite of their low level of education. The scope of this investigation is Nigeria's entertainment industry. Recorded conversations of twenty interactants in television interview were assessed (analyzed) to ascertain their prowess in discrete components of skills in spoken English. Hinging on Electicism and Communication Accommodation Theory, this study concludes that so long as some interactants with less educational qualification performed better than those with higher educational qualification, the educational qualification of speakers of Nigerian English is not a reliable parameter for determining the standard variety as far as phonology is concerned.
\end{abstract}

Keywords: Nigerian English, Standard Nigerian English, Career Nigerian English, Communication Accommodation Theory, Electicism

\section{INTRODUCTION}

The literature indicates the different classifications of Nigerian English from the strand of phonology. This study extends the literature by evolving Career Nigerian English, and contends that it is an ideal variety which is a product of individualistic efforts rather than quality education. There are several critical submissions on the supra-segmental features of Nigerian English; see Akindele and Adegbite (1999), Kujore (1985) and Jowitt (1991) for insights on these submissions. In addition, see Bamgbose (1995) and Acheoah (2013) for more tips on Nigerian English. Nigerian English discourse is replete with contentious positions on its distinctiveness within the ambit of World Englishes. This has been the situation for some decades. Much of the crisis on the distinctiveness of Nigerian English revolves around phonology; the grammar and vocabulary are less contentious till date. Indeed, there do not seem to be a strong position on the extent to which the phonology of Standard Nigerian English approximates its matrix, RP.

\section{The Research Problem}

Since the existence of Nigerian English is still contentious, proposing a new phonological variety of Nigerian English may be viewed as a problematic project. However, the objectives of this proposal are worthy of scholarly attention: to contend that as far as phonology is concerned, the educational qualification of speakers of any language is not an acceptable parameter for determining standard; to spur further research on Career Nigerian English beyond its phonological corpora. Although the literature acknowledges that level of educational qualification is not a reliable yardstick for determining speakers of Standard Nigerian English, it presents worrisome perspectives on the categorization of Nigerian English via phonology.

\section{The Classification of Nigerian English}

Bamgbose (1982) presents Brosnahan's (1958) four levels of Nigerian English categorized on the basis of formal education - cited in Babaunde (2001): 
Level 1: Pidgin (no formal education);

Level 2: Only primary education completed;

Level 3: Only secondary education completed;

Level 4: University education completed.

Education, as the literature indicates, is the common basis for classifying speakers of Nigerian English. This study aligns with Bamgbose (1982:100), cited in Babatunde (ibid.:176) who opines that although level of education is " 'an attractive parameter', it is to be used as a flexible variable, because factors such as prolonged exposure, self-help and other relevant socio-and psycho-linguistic factors could make a primary school leaver as proficient as a university graduate."

Odumuh (1987), cited in Babatunde (ibid.:177), uses level of education to evolve four varieties of spoken Nigeria English:

V1 (Non-Standard): Those having primary school education with little exposure. Their English is characterized by L1 interference and inappropriate lexical choice and use;

V2 (Basic or General): It has a fair mastery of segmental and non-segmental distinctions and can be fairly easily understood. This variety is characteristic of secondary school leavers who have especially been influenced by bad models;

V3 (Standard or Educated): It has appropriate segmental and non-segmental distinctions, and can be understood and accepted nationally and internationally. It is spoken mainly by those who have university education;

V4 (Sophisticated or Near-native): This variety is found with those who are highly educated especially those who have received a specialist training in spoken English or those with long years of exposure to native speakers. There are, however, instances of non-native usage of English here as well. Odumuh holds the view that intelligibility and communication effectiveness are the ideal parameters for determining standard. This study posits that intelligibility is a weak factor, because the phonological corpora of the lower or intermediate levels or variety of Nigerian English are also intelligible; they can be clearly heard although they are bereaved of the core supra-segmental features of RP. Unlike previous studies, this study contends that having a specialist training in spoken English is not strictly a pre-requisite for effective and intelligible speech. The specialists in Nigerian tertiary institutions are merely specialists in terms of the course contents. They teach effectively, the spoken English skills they do not exhibit due to extra-linguistic factors. Just as nobody needs the certificate of formal education to be a good actress or actor, nobody needs the certificate of formal education to imitate the speech patterns of native speakers of English. The view that long years of exposure to native speakers produce good spoken English (See Variety 2 in Odumuh's classification) is not completely acceptable because long years of exposure to native speakers can only produce RP-like speech if the non-native speakers grow up in native environment (during childhood). This study views "exposure" beyond being exposed to the rubrics of formal education or any kind of social integration. It investigates the positive linguistic consequences of exposure, to career challenges. Variety One in Odumuh's classification is questionable because it fails to acknowledge the fact that L1 interference is caused by attitudinal and socio-cultural inclinations rather than low education. L1 interference is also caused by the degree of convergence or divergence between the phonological corpora of L1 and those of the target language. Variety Two gives an impression that those who obtained Ordinary Level Certificate speak poorly because their teachers are not as educated as university Lecturers who taught these same teachers.

Although postulations in the literature are falling apart, the center can hold if the categorization of Nigerian English is strictly corpora-based rather than education-based. Variety Four shows Odumuh's unacceptable use 
of "found" and "highly educated"; while the use of "found" implies that the phonological corpora is "definitely resident in" the speakers, the use of "highly educated" implies that "having a very high educational qualification is definitely a prerequisite for speaking the corpora".

\section{THEORETICAL FRAMEWORK}

This study is anchored by two theories: Electicism and Communication Accommodation Theory. McCarthy (2001), cited in Ekerete and Babatunde (2011) makes fascinating submissions on these theoretical positions. From an elective perspective, language is both an abstract and a social phenomenon. If language is abstract, speakers' ability to explore the language cannot be restricted even by educational qualification. If language is a social phenomenon, speakers' creative and incredible use of the language should be solely individualistic rather than being education-driven. The Communication Accommodation Theory on the other hand, posits that speakers should be able to adjust pronunciation according to the contextual nuances that impinge on the communication situation. Contextual nuances are synonymous to the career-domains speakers aspire to thrive in. Essentially, CNE is the product of the extrinsic motivators in language use. The Communication Accommodation Theory emphasizes the dynamics of inter-cultural communication in multilingual milieu.

\section{METHODOLOGY}

Television conversations of twenty interviewees were recorded between January and March (See appendix) 2017. The data are restricted to the spoken English of the interviewees because the interviewers' utterances were too minimal for the purpose of this study. The assessment is based on four grades, each with a specific score: Very Good (4), Good (3), Average (2) and Poor (1). "Excellent" is excluded from the grades because adult non-native speakers of English rarely have such a level of proficiency.

\section{Data Analysis}

The researcher does not deem it necessary to transcribe the segmental and supra-segmental features of the interactants' delivery (spoken English) because a meticulous assessment of the performance of the interactants - relying on knowledge of RP and listening skills as in classroom practical assessment of students - is sufficient for the aims of this study. However, to ensure a proper analysis or assessment of the discrete skills being investigated, this researcher ensures that the skills are assessed one after the other. The researcher listened to the recording sixteen (16) times to assess: articulation of monophthongs, articulation of diphthongs and triphthongs, stress on words and stretches as well as the articulation of phonological processes such as articulation, deletion and flapping. The table below shows the performance of twenty interactants:

Table1. Performance in Spoken English

\begin{tabular}{|c|c|c|c|c|}
\hline Interactants (1-20) & $\begin{array}{c}\text { Articulation of } \\
\text { Monophthongs }\end{array}$ & $\begin{array}{c}\text { Articulation of } \\
\text { Diphthongs and } \\
\text { triphthongs }\end{array}$ & $\begin{array}{c}\text { Stress Placement } \\
\text { on Words and } \\
\text { Stretches }\end{array}$ & $\begin{array}{c}\text { Articulation of } \\
\text { Phonological } \\
\text { Processes }\end{array}$ \\
\hline $\begin{array}{c}\text { 1. Qualification: First Degree } \\
\text { Profession: Comedian }\end{array}$ & Very Good & Good & Good & Very Good \\
\hline $\begin{array}{c}\text { 2. Qualification: NCE } \\
\text { Profession: } \\
\text { Musician/Actress }\end{array}$ & Good & Good & Average & Average \\
\hline $\begin{array}{c}\text { 3. Qualification: OND } \\
\text { Profession: } \\
\text { Fashion designer }\end{array}$ & Average & Poor & Poor & Poor \\
\hline $\begin{array}{c}\text { 4. Qualification: Sch. Cert } \\
\text { Profession: Musician }\end{array}$ & Good & Good & Good & Good \\
\hline
\end{tabular}


Proposing a New Phonological Variety of Nigerian English

\begin{tabular}{|c|c|c|c|c|}
\hline $\begin{array}{l}\text { 5. Qualification: NCE } \\
\text { Profession: Actor }\end{array}$ & Very Good & Good & Good & Very Good \\
\hline $\begin{array}{l}\text { 6. Qualification: OND } \\
\text { Profession: Actor/Motivational } \\
\text { Speaker }\end{array}$ & Average & Poor & Poor & Poor \\
\hline $\begin{array}{l}\text { 7. Qualification: OND } \\
\text { Profession: Comedian }\end{array}$ & Average & Average & Average & Poor \\
\hline $\begin{array}{l}\text { 8. Qualification: First Degree } \\
\text { Profession: Actress }\end{array}$ & Average & Poor & Poor & Poor \\
\hline $\begin{array}{l}\text { 9. Qualification: NCE } \\
\text { Profession: Pastor }\end{array}$ & Good & Good & Good & Average \\
\hline $\begin{array}{l}\text { 10. Qualification: Sch. Certificate } \\
\text { Profession: Actor/Comedian }\end{array}$ & Very Good & Good & Good & Good \\
\hline $\begin{array}{c}\text { 11. Qualification: OND } \\
\text { Profession: Actress/Model }\end{array}$ & Good & Good & Good & Good \\
\hline $\begin{array}{l}\text { 12. Qualification: OND } \\
\text { Profession: Actor }\end{array}$ & Poor & Poor & Poor & Average \\
\hline $\begin{array}{l}\text { 13. Qualification: Sch. Certificate } \\
\text { Profession: Actor }\end{array}$ & Very Good & Good & Good & Good \\
\hline $\begin{array}{l}\text { 14. Qualification: Sch. Certificate } \\
\text { Profession: Musician }\end{array}$ & Good & Good & Average & Average \\
\hline $\begin{array}{l}\text { 15. Qualification: First Degree } \\
\text { Profession: Comedian/Film } \\
\text { Producer }\end{array}$ & Average & Average & Average & Average \\
\hline $\begin{array}{l}\text { 16. Qualification:Masters Degree } \\
\text { Profession: Film Producer }\end{array}$ & Good & Average & Average & Average \\
\hline $\begin{array}{l}\text { 17. Qualification: First Degree } \\
\text { Profession: Actor }\end{array}$ & Average & Poor & Poor & Poor \\
\hline $\begin{array}{l}\text { 18. Qualification: First Degree } \\
\text { Profession: Actress }\end{array}$ & Very Good & Good & Good & Good \\
\hline $\begin{array}{c}\text { 19. Qualification: NCE } \\
\text { Profession: Fashion Designer/ } \\
\text { Events Planner } \\
\end{array}$ & Average & Average & Average & Average \\
\hline $\begin{array}{l}\text { 20. Qualification: First Degree } \\
\text { Profession: Musician }\end{array}$ & Poor & Poor & Poor & Poor \\
\hline
\end{tabular}

Key: Grades and Scores:

Very Good - 4; Good - 3; Average - 2; Poor - 1

Table 2 below reveals the breakdown of the performance of the interactants as presented in table 1 above:

Table2. Breakdown of Performance

\begin{tabular}{|c|c|c|c|c|}
\hline Grades & School Certificate & NCE & OND & First Degree and Above \\
\hline Very Good & $(1) \times 4=4$ & $(2) \times 4=8$ & $(0) \times 1=0$ & $(3) \times 4=12$ \\
\hline Good & $(12) \times 3=36$ & $(7) \times 3=21$ & $(6) \times 3=18$ & $(5) \times 3=15$ \\
\hline Average & $(2) \times 2=4$ & $(3) \times 2=6$ & $(7) \times 2=14$ & $(9) \times 2=18$ \\
\hline Poor & $(0) \times 1=0$ & $(0) \times 1=0$ & $(9) \times 1=9$ & $(6) \times 1=6$ \\
\hline TOTAL & 44 & 35 & 41 & 51 \\
\hline
\end{tabular}


Proposing a New Phonological Variety of Nigerian English

Table 3 below indicates the frequencies and percentages of the four grades - an overall reflection of the quality of English spoken by stakeholders in the Nigerian entertainment industry:

Table3. Frequencies and Percentages of Grades

\begin{tabular}{|c|c|c|}
\hline Grade & Frequency & Percentage \\
\hline Very Good & 6 & $8.3 \%$ \\
\hline Good & 30 & $42 \%$ \\
\hline Average & 21 & $29 \%$ \\
\hline Poor & 15 & $21 \%$ \\
\hline
\end{tabular}

\section{Results, Discussion AND ConClusion}

This study reveals that Nigerians with higher educational qualifications can be speakers of any of the varieties or levels of Nigerian English in the literature - classifications that are too rigid in terms of speakers of each variety or level. Perhaps attention should be on the classification of Nigerian English in terms of the extent it approximates RP, so that the speaker-variable can be relegated to nothingness - thus, CNE is neither spoken only by Nigerians in the entertainment industry nor by all Nigerians in the industry.

Table 3 shows that the frequency of each grade is multiplied by the score specified for it towards arriving at the total score for each category of speakers. The fact that interactants who have attained First Degree and above scored 51, implies that non-native speakers of English speak better when they are career-driven than when they are merely certificate-inclined. The difference in the scores (performance) of the School Certificate holders and those who have attained First Degree and above (44 and 51 respectively) is not as much as the disparity between the two qualifications. In addition, since School Certificate holders performed better than those who have obtained National Diploma (ND), and National Certificate in Education (NCE) (44, 35 and 41 respectively), it can be concluded that formal education does not necessarily determine good performance in spoken English. The skills are mastered through conscious imitation and practice, rather than learning textbook tips through formal education. Table 3 also indicates that segmental phonemes are less difficult to articulate by some Nigerians who have attained either the lowest or highest qualification that formal education offers. But some of the interactants who articulate segmental phonemes properly, do not articulate glides effectively. In terms of international intelligibility and social acceptability, CNE is incredible and acceptable. If there is any suitable time to pay attention to the phonological corpora of CNE, it is now that the phonological corpora of Standard Nigerian English are still not a discrete and identifiable variety. As a result of the legitimacy of regional Englishes, CNE should be viewed as an emergent or emerging variety worthy of scholarly attention. If Received Pronunciation (RP) is not adequate for pedagogical purposes as noted by Banjo (1995:230), then CNE can be the focus of the Oral English curriculum, particularly now that Nigeria is considering the codification of Standard Nigerian English.

There are points of convergence and divergence between Nigerian English and English RP. According to Jenkins (2000), cited in Ekerete and Babatunde (2011:537) "convergence describes the processes whereby individuals shift their speech styles to become more like that of those with whom they are interacting". It is a way of ensuring that one's speech pattern closely resembles those of one's interlocutors. This may include phonetic changes or some other phonological variations. By imitating native speakers' pronunciation effectively, speakers of CNE demonstrate convergence phenomenon. On the other hand, divergence explains a sociolinguistic situation in which a member of a speech community varies his/her speech within his/heringroup and the respective outgroup of his interlocutors in order to preserve his/her positive ingroup identity. Nigerians who are stakeholders of the entertainment industry portray themselves as members of the class of superstars/celebrities by successfully articulating segmental and suprasegmental phonemes as any Hollywood star would do; this process depicts 
divergence. Speakers of CNE do not just imitate the dress styles of British and American celebrities. They also aspire to speak like these native speakers of English. Nollywood celebrities thrive to make their Spoken English commensurate with their appearance. Human beings speak language effectively by behaving in language. Performance in spoken English can be determined by attitudinal factors such as conscious efforts of Nigerians to subdue mother tongue interference and other phonological "Nigerianisms" that can make Standard Nigerian English tear apart from RP.

Indeed, many adult Nigerians who live in the US and the UK cannot still articulate better pronunciations than CNE speakers who have never travelled abroad. There is the common claim that the reason why Nigerians have difficulties in articulating RP especially at the supra-segmental level, is that their articulators (organs of speech) are already used to particular patterns of articulation. However, one keeps wondering why such Nigerians do not find it difficult to articulate RP features when singing.

CNE is an expression of the identity of its speakers. It is a tool for achieving individualistic professional aspirations. Speakers of CNE simply process native speakers' articulation patterns for present and future use. They "mean" the imitation process and get it right because they are very career-focused. Their spoken English culminates into an emergent or emerging phonological variety of Nigerian English - a variety that is pleading for relevance and attention in the literature that is already suffocated with the notion that Standard Nigerian English is spoken by Nigerians with higher educational qualifications.

\section{REFERENCES}

1. Acheoah, J. E. (2013). 'Phonology of Nigerian English', in Ayodabo J. O. and Butari P. N. (eds.). Issues in Language and Linguistics: The Nigerian Perspective, pp. 1-12. Kaduna: Language Study Group.

2. Akindele, F. and Adegbite, W. (1999). The Sociology and Politics of English in Nigeria: An Introduction. Ile-Ife: Obafemi Awolowo University Press.

3. Bamgbose A. (1995). 'English in the Nigerian Environment', in Bamgbose (ed.) New Englishes. pp. 9-26. Ibadan: Mosuro.

4. Jowitt, D. (1991). Nigerian English Usage: An Introduction. London: Longman.

5. Kujore, O. (1985). English Usage: Some Notable Nigerian Variations. Ibadan: Evans Brothers.

6. Ubong, E. J. \& Babatunde, S. T. (2011). Standard Nigerian English Phonemes: The Crisis of Modelling and Harmonization. World Englishes, Vol. No. 4 (2011):533-550.

\section{APPENDiX}

\section{Interactant 1}

"I do not think one's profession affects relationships. I have been a comedian for over twelve years, and I am still having a peaceful, happy marriage. It depends. It just depends. You see, understanding matters. A comedian plays very unique and vital roles in society. Comedy is fascinating. If that be the case, I have to live the life of a comedian. Really, the sky is the limit."

\section{Interactant 2}

"As an actress, I don't have to be shy. The tendency is there to, but you don't have to. It is always good to avoid professional misconduct. This consciousness emboldens me and... anyway, I can assure you that I have overcome stage-fright with time.

Yes, I do as well. Acting makes me a better Director. Directing is quite demanding. I have directed so many scripts incredibly." 


\section{Interactant 3}

"They are actually very many. Music is very important to the soul. So, we cannot have enough of them out there. Musicians are never too many. We need them and the various categories of music they sing. Really, my best in the Nigerian music industry is yet to emerge. Who is your best?"

\section{Interactant 4}

"Nollywood has come to stay. We the celebrities have made it happen. Let us just flow with the name. Hollywood, and then Nollywood. Okay. It is a Nigerian thing. I just love it. I can assure you that in the next decade, Nollywood will be a great source of revenue for this country. Nollywood stars have to be celebrated. Yeah, they have to."

\section{Interactant 5}

"Career issues have to be given the attention they deserve. The reason many fail to reach the peak of their career is clear: they do not have enough passion to excel in it. When you have the drive, you thrive. That is my take. Nollywood superstars for instance, are above their colleagues not because they are super-human. I hope you understand me? We all have the potentials..."

\section{Interactant 6}

"I do not know them. But they know why they are my fans. Just put in your very best, and your fans will always be out there to be yours. A big shout-out to my fans out there. Yes. Sometimes, it is the case."

\section{Interactant 7}

"You are right. There are bound to be challenges. But you have to overcome them. You have to, really. I can remember when my age was a major obstacle to my performance. I was so uncomfortable with it that I could not bring out my very best performance. Really, age shouldn't be an obstacle."

\section{Interactant 8}

"I am one of those who believe that as you dress, so you are addressed. Appearance all the same, makes a great difference. The nature of the production determines one's appearance. You just have to be conscious of this. It will be unprofessional...yes, it will be unprofessional to appear the wrong way. It is part of your packaging."

\section{Interactant 9}

"Religious drama is supposed to be didactic, as it lampoons societal vices. It took us such a problematic long time to fix some fundamental difficulties. Indeed, the play has sub-themes revolving around the main theme. Apart from using the pulpit to proclaim the gospel, it is my duty as a Pastor to convey our messages on stage to a wide range of audience."

\section{Interactant 10}

"I have been in the modeling business for a long time. Modeling predated my career as an actor and comedian. It aligns with acting and comedy. In this sense, I think your question is logical."

\section{Interactant 11}

"It essentially produces desired results. It is the key to success. Discipline actualizes dreams. If I recall some antecedents you will understand why we all need it."

\section{Interactant 12}

"I mind. I actually mind about how the characters look. It drives out my message. This consciousness is indispensible as far as effective directing of films is concerned." 


\section{Interactant 13}

"It is not necessary. Unfortunately, actors and actresses think it is a compulsory feature of the entertainment industry. If an actress is so badly dressed to the level of nudity, it is unacceptable. It is unfortunate. Mr. Kelvin, The industry is not about exposing the body as you rightly put it."

\section{Interactant 14}

"Wao! Piracy is the real problem with the industry these days. What happens is all about survival of the fittest. My take remains that the appropriate government agency has done little or nothing to stem the tide. Although piracy is not confined to Nigeria, it is very common."

\section{Interactant 15}

"Those who think so are right. Public performances promote the artist's popularity. But some problems are peculiar to public performances. Of course, I have had good and bad experiences over the years. I was in Lagos in 2014 for an incredible musical concert."

\section{Interactant 16}

"Inter-ethnic marriage became a source of inspiration to me. Before my career proper, I had a very different mindset - quite different from the views I hold today concerning marriage between individuals from different ethnic backgrounds. I have done my best to articulate such views into the film industry."

\section{Interactant 17}

"It doesn't really have to be. I am aware that human beings have different likes and dislikes. Understand me: I will retain the colour of my skin. It is what makes me African. Know me with my roots. Black, light complexion, brown...just don't mind."

\section{Interactant 18}

"It depends on the way you look at it. The musicians of those decades were so amazing in lyrics and rhythm. I can continue to name them. But you see, that doesn't make past Nigerian music better than the contemporary ones. It is a choice thing. Choice is individualistic and generational."

\section{Interactant 19}

"Am I not physically fit for the industry?"

Yet my critics say terrible things about my size. Abah. That is not what they need. Simply play the roles amazingly. That's what you need. Be confident about your appearance."

\section{Interactant 20}

"I still strongly hold the view that themes must be relevant to the needs of society. In music or drama, project the core message. Be the expected ambassador. As you know, the movie is about the consequences of infidelity."

Citation: Acheoah John Emike, "Proposing a New Phonological Variety of Nigerian English" American Research Journal of English and Literature, vol 4, no. 1, 2018, pp. 1-8.

Copyright (c) 2018 Acheoah John Emike, This is an open access article distributed under the Creative Commons Attribution License, which permits unrestricted use, distribution, and reproduction in any medium, provided the original work is properly cited. 